\title{
NBS1 rs2735383 polymorphism is associated with an increased risk of laryngeal carcinoma
}

\author{
Xinmei $\mathrm{Hu}^{1 \dagger}$, Juan Liao ${ }^{1 \dagger}$, Huiliu Zhao ${ }^{2}$, Feng Chen ${ }^{3}$, Xuefeng Zhu' ${ }^{1}$, Jiangheng $\mathrm{Li}^{1}$ and Qingqing Nong ${ }^{1,4^{*}}$
}

\begin{abstract}
Background: Nijmegen breakage syndrome 1 (NBS1), as a key protein in the DNA double-strand breaks (DSBs) repair pathway, plays an important role in maintaining genomic stability. Although single nucleotide polymorphisms (SNPs) in NBS1 have frequently been studied in multiple cancers, the relationships of two functional NBS1 polymorphisms (rs2735383 and rs1805794) with laryngeal carcinoma are yet unclear. Therefore, in the present study, we performed a case-control study including 342 cases and 345 controls to analyze the associations between two polymorphisms of NBS1 and the risk of laryngeal carcinoma.

Methods: We used the polymerase chain reaction-restriction fragment length polymorphism (PCR-RFLP) method to determine the genotypes of the functional SNPs in NBS1 gene.

Results: In comparison with the homozygous rs2735383GG genotype, the CC genotype was significantly associated with an increased risk of laryngeal carcinoma (adjusted $\mathrm{OR}=1.884,95 \% \mathrm{Cl}=1.215-2.921$ ). The rs2735383C variant genotypes (GC + CC) conferred a 1.410-fold increased risk of laryngeal carcinoma (adjusted $\mathrm{OR}=1.410,95 \% \mathrm{Cl}=1.004-1.980$ ). Furthermore, when compared to rs2735383GG genotype in laryngeal carcinoma tissues, the combined GC and CC genotypes exerted a significantly lower mRNA level of NBS1 $(P=0.003)$. In contrast, no significant association was found between rs1805794G > $C$ polymorphism and cancer risk (adjusted $\mathrm{OR}=1.074,95 \% \mathrm{Cl}=0.759-1.518$ for $\mathrm{GC}$; adjusted $\mathrm{OR}=1.100,95 \% \mathrm{Cl}=0.678-1$. 787 for CC; adjusted $\mathrm{OR}=1.079,95 \% \mathrm{Cl}=0.774-1.505$ for $\mathrm{GC}+\mathrm{CC})$.
\end{abstract}

Conclusions: These findings indicate that rs2735383G > C polymorphism in NBS1 may play a crucial role in the development of laryngeal carcinoma.

Keywords: NBS1, Laryngeal carcinoma, Polymorphism

\section{Background}

Laryngeal carcinoma is one of the most common malignant tumors. According to the data from International Agency for Research on Cancer, it accounts for 30\% to $40 \%$ of head and neck malignancies and $1 \%$ to $2.5 \%$ of all malignant neoplasms in human, respectively [1]. Although the overall incidence is declining [2], laryngeal cancer is still an unignorable health issue throughout the

\footnotetext{
*Correspondence: nnqq@gxmu.edu.cn

${ }^{\dagger}$ Equal contributors

'School of Public Health, Guangxi Medical University, 22 Shuangyong Road, Nanning, Guangxi 530021, China

${ }^{4}$ Guangxi Colleges and Universities Key Laboratory of Prevention and Control of Highly Prevalent Diseases, Guangxi Medical University, Nanning 530021, China

Full list of author information is available at the end of the article
}

world. In the Netherlands, about 700 people are diagnosed with laryngeal carcinoma annually [3]. In China, the incidence of laryngeal carcinoma is only secondary to nasopharyngeal carcinoma among all types of head and neck cancers. In some regions, its incidence is even the highest [4].

Epidemiological studies have established many etiologic factors of laryngeal cancer, including smoking and alcohol consumption [5]. These above factors can potentially modify DNA, cause genomic instability, and thus lead to carcinogenesis. Efficient and accurate repairs of DNA damage could maintain the stability of genome. However, deficiencies of DNA double-strand breaks (DSBs) repair might sensitize carcinogens induced genomic instability and cancer [6]. The repair of DSBs in 
human cells includes two different pathways: homologous recombination (HR) and non-homologous endjoining (NHEJ) pathways [7-9]. As a component of MRE11-RAD50-NBS1 (MRN) complex, Nijmegen breakage syndrome 1 (NBS1) plays a key role in the DSBs repair pathway and participates in both $H R$ pathway and NHEJ pathway [10]. Several reports have described the associations between SNPs in NBS1 and human cancer risks [11-14]. However, the association of NBS1 gene's variations with laryngeal carcinoma has been rarely substantiated. Ziólkowska I et al. demonstrated that heterozygous carriers of c.I171V variant were prone to the development of larynx cancer [15]. Nowak J et al. reported that NBS1 g.657del5 contributed significantly to a higher risk of laryngeal carcinoma [16]. However, the frequencies of these loci are rare in Chinese. Nevertheless, these data suggested the NBS1 might be a susceptible gene of laryngeal carcinoma.

As one of the most commonly studied polymorphisms in NBS1, rs1805794 (c.553G > C) has been shown to increase susceptibility in multiple cancers, such as acute myeloid leukemia [17], hepatic cancer [18] and lung cancer [19]. The transition of $\mathrm{G}$ to $\mathrm{C}$ resulted in reduced DNA repair capacity of NBS1 and promoted tumor migration [19, 20]. Another well-studied SNP rs2735383 (g.90947269G > C) in the 3'-UTR of NBS1 has also been studied for multiple times [13]. Recent studies found that rs2735383 was associated with substantially increased risk of colorectal cancer [21] and lung cancer [22]. This SNP was also functional by decreasing NBS1 expression [22]. However, the functions of these two variants on laryngeal carcinoma were yet unclear. Thus, we hypothesized that rs1805794G > C and rs2735383G > C might affect the DNA repair ability of NBS1 and contribute to laryngeal carcinoma.

In this study, we performed a case-control study to investigate the association between these two polymorphisms of NBS1 and the risk of laryngeal carcinoma in Han or Zhuang population in Guangxi Province of China.

\section{Methods}

\section{Study subjects}

In this study, 342 patients with histopathologically diagnosed primary laryngeal carcinoma were recruited between 2014 and 2016 in the Affiliated Tumor Hospital of Guangxi Medical University. They had a response rate of $95 \%$ among all cancer patients diagnosed in the hospital. Clinical and pathological information on all laryngeal carcinoma diagnoses were confirmed by manual review of the pathology reports and endoscopic findings of Otorhinolaryngology Department. Of the 342 cases, 37 were poorly differentiated squamous cell carcinoma (SCC), 63 were moderately differentiated SCC, 76 were well- differentiated SCC, and 166 remain unknown. Totally, 345 cancer-free controls who have matched age $( \pm 5$ years) and sex with the cases were recruited from the same hospital. These control individuals had a response rate of $84 \%$. We only recruited people whose ethnicity is Han or Zhuang.

After having given a written informed consent, all individuals were interviewed according to a structured questionnaire in order to collect personal information including age, sex, smoking status, drinking status and so on. The participants who have smoked less than 100 cigarettes in their lifetime were defined as neversmokers; otherwise were defined as ever-smokers [23]. Similarly, the participants who have consumed alcohol at least once a week for more than one year were defined as alcohol ever-drinkers and the remaining as alcohol never-drinkers [24]. Each study participant was asked to donate a one-time blood sample of $5 \mathrm{ml}$ for later examination. This study was approved by the Medical Ethics Committee of Guangxi Medical University (GXMU-20140307-4).

\section{Genotyping analysis}

Based on the previous studies [25-27], we selected and genotyped two NBS1 SNPs (rs1805794G $>\mathrm{C}$ in exon 5 and rs2735383G>C in 3'-UTR). According to the dbSNP database, the current study defined the $\mathrm{C}$ allele of both SNPs in the antisense strand (i.e., the corresponding allele is $\mathrm{G}$ in the sense strand in the database) as minor allele $[20,22]$. We used the polymerase chain reaction-restriction fragment length polymorphism (PCR-RFLP) method in Zheng's study [20] to verity the association between NBS1 polymorphism and laryngeal carcinoma risk.

The primer pairs used to amplify the DNA fragment containing the rs1805794G $>C$ polymorphism were 5'-ACCTT TCAAT TTGTG GAGGC-3' (forward) and 5'-AGTCG GTCTT TGGTC ACTGC-3' (reverse), to produce a fragment of $289 \mathrm{bp}$. The primer pairs for rs2735383G >C were 5'-TGCAG TGTTC TACAC CTTGC TT-3' (forward) and 5'AGGTG ACATC TGCAC CACTG-3' (reverse), to produce a fragment of $156 \mathrm{bp}$. PCR was performed in a $25 \mu \mathrm{l}$ reaction system, containing $5 \mathrm{mM} \mathrm{MgCl}$, $0.1 \mathrm{mM}$ deoxynucleotide triphosphates, $3.0 \mathrm{U}$ of Taq polymerase (MBI Fermentas, Vilnus, Lithuania), and the manufacturer's buffer. After an initial melting step at $94{ }^{\circ} \mathrm{C}$ for $5 \mathrm{~min}$, the PCR procedure consists of 35 cycles including denature at $94{ }^{\circ} \mathrm{C}$ for $45 \mathrm{~s}$, anneal at $62.9{ }^{\circ} \mathrm{C}$ for $\mathrm{rs} 1805794$ or $61.0{ }^{\circ} \mathrm{C}$ for rs 2375383 for $45 \mathrm{~s}$, and extension at $72{ }^{\circ} \mathrm{C}$ for $45 \mathrm{~s}$, followed by a final extension step at $72{ }^{\circ} \mathrm{C}$ for $7 \mathrm{~min}$. The amplified fragment containing rs1805794 polymorphism was cut by Hinf1 (Takara BioTech, 
Dalian, China) at $37{ }^{\circ} \mathrm{C}$ for at least $3 \mathrm{~h}$. The major $\mathrm{G}$ allele produced a single 289 bp band, while the minor C allele produced 30- and 259-bp bands. The digestion products were separated and visualized in 3\% agarose gel electrophoresis. Meanwhile, the amplified fragment containing rs2735383 polymorphism was cut by $C v i \mathrm{QI}$ (New England Biolabs, Beijing, China) at $25{ }^{\circ} \mathrm{C}$ for at least $3 \mathrm{~h}$. The minor $\mathrm{G}$ allele produced a single 156-bp band, while the major $\mathrm{C}$ allele produced two separate bands of 57-bp and 99-bp.

\section{Detection of NBS1 mRNA expression by real-time PCR}

Total RNA from 32 laryngeal carcinoma tissues were extracted using TriPure Reagent (Roche Applied Science) and reverse transcribed to complementary DNA using cDNA synthesis kit ThermoScrept ${ }^{\mathrm{TM}}$ RT-PCR System (Invitrogen). The relative mRNA expression levels of NBS1 covering rs2735383 site and $\beta$-actin (as an internal reference) were measured by the ABI Prism 7500 Sequence Detection Systems (Applied Biosystems) using the SYBR-Green method, with the same baseline and threshold set for each plate to generate threshold cycle $(\mathrm{Ct})$ values for both genes in each sample. The primers used for detection of NBS1 were as follows: $5^{\prime}$-TTGGT TGCAT GCTCT TCTTG-3' (forward) and 5'-GGCTG CTTCT TGGAC TCAAC-3' (reverse); and for $\beta$-actin 5'-GGCGG CACCA CCATG TACCC T-3' (forward) and 5'-AGGGG CCGGA CTCGT CATAC T-3' (reverse). The $2^{-\triangle \Delta C t}$ method was used to measure the level of NBS1 gene's expression.

\section{Statistical analysis}

We used Chi-square $\left(\chi^{2}\right)$ test to analyze the differences of selected characteristics (age, sex, ethnicity, smoking status and drinking status) between cases and controls. Hardy-Weinberg equilibrium (HWE) was tested using a goodness-of-fit $\chi^{2}$ test by comparing the expected genotype frequencies with that of the controls. The associations between the two polymorphisms of NBS1 and risk of laryngeal carcinoma were respectively calculated by odds ratios (ORs) with 95\% confidence intervals (CIs) using a unconditional logistic regression model, after adjusting age, sex, smoking status and drinking status. Student's $t$-test was used to evaluate the differences in NBS1 mRNA expression between different groups. All tests were analyzed using the Stata 13.0 software (Stata Corp LP, College Station, Texas, United States). The statistical power was calculated by using the PS Software (http://biostat.mc.vanderbilt.edu/twiki/bin/view/Main/Po werSampleSize). $\quad P<0.05$ was considered statistically significant.

\section{Results}

Associations between the NBS1 SNPs and laryngeal carcinoma risk

In order to determine whether the rs1805794 and rs2735383 polymorphisms of NBS1 gene are associated with laryngeal carcinoma, we examined the genotypic distribution of these two polymorphisms of NBS1 in both cases and controls. In this study, 342 laryngeal carcinoma cases and 345 controls were examined. The basic characteristics of laryngeal carcinoma cases and controls were shown in Table 1. There were no significant differences in distributions of sex, age, and ethnicity between cases and controls $(P>0.05$ for all), while the smoking status and drinking status were significantly different between cases and controls $(P=0.024$ and $P=0.000$ respectively).

The genotype distributions of rs1805794 and rs2735383, and their respective associations with laryngeal carcinoma risk are summarized in Table 2. The observed genotype frequencies of these two SNPs among the control subjects were all in agreement with the Hardy-Weinberg Equilibrium $(P=0.081$ for $\mathrm{rs} 1805794$ and $P=0.963$ for rs2735383). As shown in Table 2, the respective frequencies of rs 2735383 GG, GC and CC genotypes in the cases were $26.608 \%, 47.076 \%, 26.316 \%$, differing significantly from $33.043 \%, 48.986 \%, 17.971 \%$ in the controls $(P=$ $0.019)$. The logistical model showed that rs2735383CC variant genotype conferred a significantly increased risk of laryngeal carcinoma in comparison with the common genotype of GG (adjusted $\mathrm{OR}=1.884, \quad 95 \% \quad \mathrm{CI}$ $=1.215-2.921$ ), but the GC genotype fails (adjusted $\mathrm{OR}=1.236,95 \% \mathrm{CI}=0.861-1.775)$. When combining these two genotypes, the rs2735383C variant genotypes $(\mathrm{GC}+\mathrm{CC})$ contributed to a 1.410 -fold increased risk of laryngeal carcinoma in comparison to that of the GG genotype (adjusted OR $=1.410$, 95\% CI $=1.004-$ 1.980). The $C$ allele of rs 2735383 in a dose-dependent model was associated with an increased cancer risk $\left(P_{\text {trend }}=0.005\right)$.

In contrast, no significant association was observable between rs1805794G $>C$ polymorphism and the risk of laryngeal carcinoma $(P=0.917$, adjusted $\mathrm{OR}=1.074,95 \% \mathrm{CI}=0.759-1.518$ for $\mathrm{GC}$; adjusted $\mathrm{OR}=1.100,95 \% \mathrm{CI}=0.678-1.787$ for $\mathrm{CC}$; adjusted $\mathrm{OR}=1.079,95 \% \mathrm{CI}=0.774-1.505$ for $\mathrm{GC}+\mathrm{CC})$. Combined analyses were conducted to evaluate the cumulative effect of rs1805794 and rs2735383 (Additional file 1). In comparison with the homozygous genotypes, the combined variant genotypes were not significantly associated with increased laryngeal carcinoma risk. Thus, our study demonstrated that NBS1 SNPs rs2735383G > C might be associated with the elevated risk of laryngeal carcinoma. We then focused on SNP rs2735383 in the following analyses. 
Table 1 The selected characteristics between laryngeal carcinoma cases and controls used for association study

\begin{tabular}{|c|c|c|c|}
\hline & $\begin{array}{l}\text { Cases } \\
(n=342)\end{array}$ & $\begin{array}{l}\text { Controls } \\
(n=345)\end{array}$ & $P^{a}$ \\
\hline & N (\%) & N (\%) & \\
\hline \multicolumn{4}{|l|}{ Sex } \\
\hline Male & 333(97.368) & $334(96.812)$ & 0.664 \\
\hline Female & $9(2.632)$ & 11(3.188) & \\
\hline \multicolumn{4}{|l|}{ Age(years) } \\
\hline$<30$ & $1(0.292)$ & $2(0.580)$ & 0.864 \\
\hline $30-59$ & $150(43.860)$ & 154(44.638) & \\
\hline $60-89$ & $191(55.848)$ & 188(54.492) & \\
\hline$\geq 90$ & $0(0.000)$ & $1(0.290)$ & \\
\hline \multicolumn{4}{|l|}{ Ethnicity } \\
\hline Han & $231(67.544)$ & 238(68.986) & 0.685 \\
\hline Zhuang & $111(32.456)$ & 107(31.014) & \\
\hline \multicolumn{4}{|l|}{ Smoking status } \\
\hline ever & $223(65.205)$ & 196(56.812) & 0.024 \\
\hline never & 119(34.795) & 149(43.188) & \\
\hline \multicolumn{4}{|l|}{ Drinking status } \\
\hline ever & $176(51.462)$ & $100(28.986)$ & 0.000 \\
\hline never & $166(48.538)$ & $245(71.014)$ & \\
\hline \multicolumn{4}{|l|}{ Classification of diagnosis } \\
\hline $\begin{array}{l}\text { poorly differentiated squamous } \\
\text { cell carcinoma }\end{array}$ & $37(10.819)$ & & \\
\hline $\begin{array}{l}\text { Moderately differentiated } \\
\text { squamous cell carcinoma }\end{array}$ & $63(18.421)$ & & \\
\hline $\begin{array}{l}\text { well-differentiated squamous } \\
\text { cell carcinoma }\end{array}$ & $76(22.222)$ & & \\
\hline Unknown & 166(48.538) & & \\
\hline
\end{tabular}

${ }^{\mathrm{a}} \mathrm{A} \mathrm{X}^{2}$ test for differences in selected characteristics between cases and controls

\section{Stratification analysis}

Next, we tried to stratify the subjects according to different factors and then determined the effects of SNP rs2735383 on laryngeal carcinoma risk. As showed in Table 3, the rs2735383C variant genotypes $(\mathrm{GC}+\mathrm{CC})$ were significantly associated with an increased risk of laryngeal carcinoma in the male subgroup (adjusted OR = $1.505,95 \% \mathrm{CI}=1.066-2.126)$ and the ever-smoker subgroup (adjusted $\mathrm{OR}=1.602,95 \% \mathrm{CI}=1.023-2.510$ ). But we failed to observe any significant interactions between NBS1 polymorphisms and these two confounding factors (all $P_{\text {interaction }}>0.05$ ), possibly due to the limited sample size in each subgroup.

\section{Association of the rs2735383G > C genotype and NBS1 mRNA expression level}

As shown in Fig. 1(a), among 32 laryngeal carcinoma tissues examined, the tissues of $\mathrm{CC}$ genotype have significantly lower mRNA expression $(0.12 \pm 0.06$ for 7 cases with $\mathrm{CC}$ ) of NBS1 than those with GC or GG genotype $(0.23 \pm 0.12$ for 16 cases with $\mathrm{GC}$ and 0.29 \pm 0.13 for 9 cases with GG; ANOVA test: $P=0.02$ ). Furthermore, as seen in Fig. 1(b), the dichotomized analysis showed that the mRNA levels of NBS1 from those tissues with combined $\mathrm{GC}$ and $\mathrm{CC}$ genotypes $(0.18 \pm 0.09$ for 23 cases with $\mathrm{GC}+\mathrm{CC})$ were significantly lower than that of GG genotype (0.29 \pm 0.13 for 9 cases with GG; Student's $t$-test: $P=0.003)$.

\section{Discussion}

In the present study, we analyzed the associations between two common NBS1 SNPs (rs1805794G > C and rs2735383G > C) and laryngeal carcinoma risk in 342 laryngeal carcinoma cases and 345 controls. We found that the rs2735383C variant genotypes $(\mathrm{GC}+\mathrm{CC})$ contributed an increased risk to laryngeal carcinoma. The risk also increased as the number of rs2735383C allele increased. The NBS1 mRNA expression level of the rs2735383CC genotype was lower in laryngeal carcinoma tissues compared to that of GC or GG genotype. Thus, our study validated the hypothesis that rs2735383G > C polymorphism of NBS1 gene was associated with the increased risk of laryngeal carcinoma. In contrast, there was no significant difference for rs1809754G > C variant compared to common homozygous genotype.

NBS1 is one of the DNA homologous recombination repair protein, and belongs to the MRE11RAD50-NBS1 complex. It plays a crucial role in maintaining genomic stability because the hMRE11/ hRAD50/NBS1 protein complex functions as a sensor to detect DNA damage [10]. Mutations in NBS1 may cause Nijimegen breakage syndrome (NBS), which is characterized by radiosensitivity, immunodeficiency, chromosomal instability and an increased risk for cancer [28]. Multiple studies have established the essential roles of NBS1 protein in DSBs repair and tumor development in multiple types of tumor, including ovarian tumors [25], lung cancer [26], non-Hodgkin lymphoma [29] and sporadic breast cancer [30].

NBS1 rs1805794 polymorphism, which has frequently been studied, is associated with risks of breast cancer [27], cervix carcinoma [31], nasopharyngeal carcinoma [20], and bladder cancer [32]. Moreover, functional studies have demonstrated that the rs $1805794 \mathrm{G}>\mathrm{C}$ is functional and could recede the DNA repair capacity of NBS1 [19]. This transition also impairs NBS1's capacity of inhibiting tumor invasion [20]. However, NBS1 rs1805794G $>C$ is not always associated with cancer risk. For example, a study found that the rs1805794 variant genotype was not associated with the risk of some tumors, including head and neck cancers in a Polish 
Table 2 Frequency distribution of genotypes in NBS1 and results of logistic regression analysis for their associations with laryngeal carcinoma risk

\begin{tabular}{|c|c|c|c|c|c|}
\hline \multirow[t]{2}{*}{ Genotypes } & \multirow{2}{*}{$\begin{array}{l}\text { cases } \\
N(\%)\end{array}$} & \multirow{2}{*}{$\begin{array}{l}\text { controls }^{a} \\
\mathrm{~N}(\%)\end{array}$} & \multirow[t]{2}{*}{$p^{\mathrm{b}}$} & \multirow[t]{2}{*}{ Crude OR (95\%Cl) } & \multirow{2}{*}{$\begin{array}{l}\text { Adjusted OR } \\
(95 \% \mathrm{Cl})^{\mathrm{C}}\end{array}$} \\
\hline & & & & & \\
\hline Total no. of subjects & 342 & 345 & & & \\
\hline \multicolumn{6}{|l|}{ rs1805794(G > C) } \\
\hline GG & $105(30.702)$ & $111(32.174)$ & 0.917 & 1.000 (ref) & 1.000 (ref) \\
\hline GC & $185(54.094)$ & $183(53.043)$ & & 1.069 (0.764-1.496) & $1.074(0.759-1.518)$ \\
\hline CC & $52(15.205)$ & $51(14.783)$ & & $1.078(0.674-1.724)$ & $1.100(0.678-1.787)$ \\
\hline Trend test $P$ value & & & & 0.707 & 0.660 \\
\hline$G C+C C$ & $237(69.298)$ & $234(67.826)$ & & $1.071(0.776-1.478)$ & $1.079(0.774-1.505)$ \\
\hline \multicolumn{6}{|l|}{ rs2735383(G > C) } \\
\hline GG & $91(26.608)$ & $114(33.043)$ & 0.019 & 1.000 (ref) & 1.000 (ref) \\
\hline GC & $161(47.076)$ & $169(48.986)$ & & $1.193(0.841-1.694)$ & $1.236(0.861-1.775)$ \\
\hline CC & $90(26.316)$ & $62(17.971)$ & & $1.819(1.189-2.781)$ & $1.884(1.215-2.921)$ \\
\hline Trend test $P$ value & & & & 0.007 & 0.005 \\
\hline $\mathrm{GC}+\mathrm{CC}$ & $251(73.392)$ & $231(66.957)$ & & $1.361(0.980-1.890)$ & $1.410(1.004-1.980)$ \\
\hline
\end{tabular}

${ }^{a}$ The observed genotype frequencies of the two SNPs among the control subjects were all in agreement with the Hardy-Weinberg equilibrium $(P>0.05$ for all $)$

${ }^{\mathrm{b}} \mathrm{A} \mathrm{x}^{2}$ test for differences in distribution of genotype frequencies between cases and controls

${ }^{c}$ Adjusted in a unconditional logistic regression model that included age, sex, smoking status and drinking status

population [33]. Similarly, our present results also showed that the polymorphism rs1805794G $>$ C was not associated with the risk of laryngeal carcinoma. Some researchers found that rs1805794GC conferred a 1.68-fold risk of larynx cancer compared with GG genotype, which is different from our study [15]. The reason for such discrepancies in results may be that our study is only related to Han and Zhuang Chinese.

The other examined rs2735383G >C polymorphism locates in the 3'-UTR of NBS1. Yang et al. demonstrated that rs2735383G $>C$ was functional by decreasing NBS1 expression via formation of a novel

Table 3 Stratification analysis of the NBS1 rs2735383 genotypes by selected variables in laryngeal carcinoma cases and controls

\begin{tabular}{|c|c|c|c|c|c|c|}
\hline & \multicolumn{2}{|c|}{$\operatorname{cases}(n=342)$} & \multicolumn{2}{|c|}{ controls $(n=345)$} & \multirow{3}{*}{$\begin{array}{l}\text { Adjusted OR }(95 \% \mathrm{Cl})^{\mathrm{a}} \\
\mathrm{GC}+\text { CC vs GG }\end{array}$} & \multirow[t]{3}{*}{$P_{\text {interaction }}^{\mathrm{b}}$} \\
\hline & $\overline{G G}$ & $\mathrm{GC}+\mathrm{CC}$ & $\overline{G G}$ & $\mathrm{GC}+\mathrm{CC}$ & & \\
\hline & N (\%) & N (\%) & N (\%) & N (\%) & & \\
\hline \multicolumn{7}{|l|}{ Age } \\
\hline$\leq 60$ & $49(14.327)$ & $113(33.041)$ & $61(17.681)$ & $109(31.594)$ & $1.306(0.811-2.106)$ & \multirow[t]{2}{*}{0.080} \\
\hline$>60$ & $42(12.281)$ & $138(40.351)$ & $53(15.362)$ & $122(35.363)$ & 1.496 (0.919-2.436) & \\
\hline \multicolumn{7}{|l|}{ Sex } \\
\hline Male & $87(25.439)$ & $246(71.930)$ & $113(32.754)$ & $221(64.058)$ & $1.505(1.066-2.126)$ & \multirow[t]{2}{*}{0.762} \\
\hline Female & $4(1.170)$ & $5(1.461)$ & $1(0.290)$ & $10(2.898)$ & $0.127(0.010-1.549)$ & \\
\hline \multicolumn{7}{|l|}{ Ethnicity } \\
\hline Han & $62(18.129)$ & $169(49.415)$ & $81(23.478)$ & $157(45.507)$ & $1.439(0.954-2.169)$ & \multirow[t]{2}{*}{0.526} \\
\hline Zhuang & $29(8.480)$ & $82(23.977)$ & $33(9.565)$ & $74(21.449)$ & $1.394(0.755-2.573)$ & \\
\hline \multicolumn{7}{|c|}{ Smoking status } \\
\hline Ever & $62(18.129)$ & $161(47.076)$ & $73(21.159)$ & $123(35.652)$ & $1.602(1.023-2.510)$ & \multirow[t]{2}{*}{0.152} \\
\hline Never & $29(8.480)$ & $90(26.316)$ & $41(11.884)$ & $108(31.304)$ & $1.191(0.681-2.083)$ & \\
\hline \multicolumn{7}{|c|}{ Drinking status } \\
\hline Ever & $53(15.497)$ & $123(35.965)$ & $33(9.565)$ & $67(19.420)$ & $1.225(0.703-2.133)$ & \multirow[t]{2}{*}{0.907} \\
\hline Never & $38(11.111)$ & $128(37.427)$ & $81(23.478)$ & $164(47.536)$ & $1.594(0.985-2.514)$ & \\
\hline
\end{tabular}

${ }^{\mathrm{a}}$ ORs were adjusted for age, sex, smoking status, drinking status

${ }^{\mathrm{b}} P$ value of a test the multiplicative interaction between rs 2735383 and selected variables on cancer risk were calculated using logistic regression models 

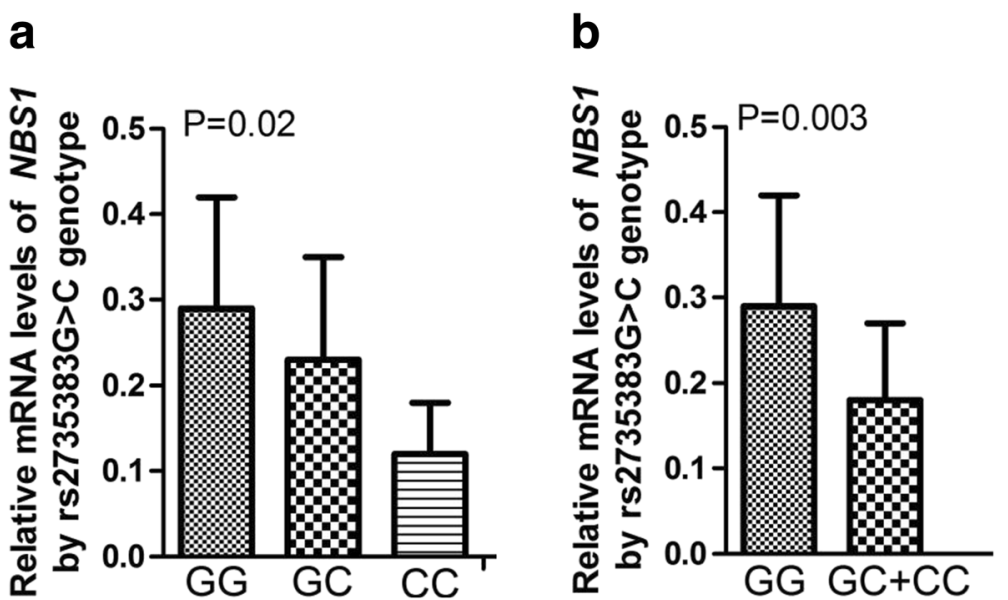

Fig. 1 The relative mRNA levels of NBS1 by rs2735383G > C genotype. a The differences in the mRNA expression levels were analyzed by ANOVA test. b After combined GC and CC, the differences in the expression levels were analyzed by Student's $t$-test

binding site of microRNA-629 to the 3'-UTR of NBS1 gene [22]. Some researchers found that rs2735383G > $\mathrm{C}$ in NBS1 was significantly associated with the risks of colorectal cancer [21] and lung cancer [22]. Although some studies revealed an insignificant association between rs2735383G $>\mathrm{C}$ and breast cancer risk [34-36], this SNP was significantly associated with progestrone receptor positivity of breast cancer patients [36]. The present study is the first to investigate the association between NBS1 rs2735383 and the risk of developing laryngeal carcinoma. Our results supported the conclusion that the NBS1 rs2735383 polymorphism was associated with laryngeal carcinoma risk. In addition, c.I171V and g.657del5 have been reported to be risk loci of laryngeal carcinoma in other ethnics $[15,16]$, but we did not test these two loci because they are rare in Chinese. All the above results suggest that the role of NBS1 polymorphism in laryngeal carcinoma risk may be affected by some ethnic difference, which warrants further investigations.

In this study, we investigated the associations between the SNPs (rs2735383 and rs1805794) and the risks of laryngeal carcinoma. We also took into consideration the relevant factors of age, sex, smoking status and drinking status, all of which might be a major cause of laryngeal carcinoma. However, there are still some limitations in our study. For example, the scale of our study subject group is relatively small. And other factors such as family cancer history may interact with genotype, but this information was unavailable in our casecontrol study. Due to the fact that our study was a hospital-based case-control one and that our study subjects came from only the Chinese Han and Zhuang ethnicities, some selection biases were unavoidable in this study. Moreover, a considerable proportion of patients were lack of clinical stages and cancer differentiation status, thus limiting our analysis on association between NBS1 variants and clinical features. Nevertheless, our subject selection met the requirement of randomness because the genotype frequencies among controls fitted the Hardy-Weinberg disequilibrium law. We achieved over $95 \%$ study power (two-sided test, $\alpha=0.05$ ) to detect an OR of 1.884 for the rs $2735383 C \mathrm{C}$ and an OR of 1.410 for the rs2735383 GC + CC, compared to that of the rs2735383GG genotype, suggesting that our findings are well worthy.

In addition, we found that the expression of NBS1 gene in laryngeal carcinoma tissues differed with genotype of rs2735383. This indicated that the rs2735383 G>C polymorphism is a functional locus. Bioinformatics analysis with the 1000 Genomes Project (https://www.ncbi.nlm.nih.gov/variation/tools/ 1000genomes/) showed that rs2735383 G>C was in complete linkage disequilibrium with rs1063053G > A and rs1063054 A > C. The prediction using SNPinfo Web Server (https://manticore.niehs.nih.gov/) revealed that these two SNPs are both potently functional. The transition from common allele $\mathrm{G}$ of rs1063053 to variant allele A may lose binding site of hsa-miR-517b, and rs1063054A $>\mathrm{C}$ could result in new binding site of hsa-miR-654-3p but losing binding site of hsa-miR-513a-3p. These findings further indicate that the functional polymorphism rs2735383G $>C$ in the 3'-UTR of NBS1 gene could predict the risk of laryngeal carcinoma.

\section{Conclusions}

Taken together, the present study observed a significantly higher frequency of the rs 2735383 variant of the 
NBS1 gene, indicating that this variant may be a genetic susceptibility factor of laryngeal carcinoma. To the best of our knowledge, this study provided the first evidence that rs2735383G > C polymorphism in NBS1 is associated with the increased risk of developing laryngeal carcinoma. But these findings need to be verified in future case-control studies of larger sample size and better mechanism-oriented study design.

\section{Additional file}

Additional file 1: Table S1. Combined analysis of the cumulative effect of rs 1805794 and rs2735383 on laryngeal carcinoma risk. (DOC $34 \mathrm{~kb}$ )

\section{Abbreviations}

ANOVA: Analysis of Variance; Cl: Confidence interval; DSBs: DNA doublestrand breaks; HR: Homologous recombination; HWE: Hardy-weinberg equilibrium; MRN: MRE11-RAD50-NBS1; NBS1: Nijmegen breakage syndrome 1; NHEJ: Non-homologous end-joining; OR: Odds ratio; PCR-RFLP: Polymerase chain reaction-restriction fragment length polymorphism; SCC: Squamous cell carcinoma; SNPs: Single nucleotide polymorphisms

\section{Acknowledgements}

We would like to express our sincere thanks to all the subjects who have taken part in the study. We thank Mr. Hongkuang Wei and Mr. Yaoping Guo for their assistance in recruiting the subjects; Ms. Jianmin Qin and Ms. Yu Fan for their laboratory assistance.

\section{Funding}

This study was supported by grants from the National Natural Scientific Foundation of China (No.81360420 and No.81660529), and partly grants by the Guangxi Natural Science Foundation (No.2015GXNSFAA139120).

\section{Availability of data and materials}

The datasets of the current study are available from the corresponding author on reasonable request.

\section{Authors' contributions}

QN conceived and designed the study; XH, JL, XZ, JL, HZ and FC undertook data collection; $X H$, JL and $X Z$ performed the experiments. $X H$ and $J$ analyzed the data and wrote the manuscript. All authors read and approved the final manuscript.

\section{Ethics approval and consent to participate}

This study was approved by the Medical Ethics Committee of Guangxi Medical University. Written informed consent was obtained from the all included subjects.

\section{Consent for publication}

Not applicable.

\section{Competing interests}

The authors declare that they have no competing interests.

\section{Publisher's Note}

Springer Nature remains neutral with regard to jurisdictional claims in published maps and institutional affiliations.

\section{Author details}

${ }^{1}$ School of Public Health, Guangxi Medical University, 22 Shuangyong Road, Nanning, Guangxi 530021, China. ${ }^{2}$ Department of Clinical Laboratory, The Affiliated Tumor Hospital of Guangxi Medical University, Nanning, Guangxi, China. ${ }^{3}$ Department of Medical Oncology Division, The First Affiliated Hospital of Guangxi Medical University, Nanning, Guangxi, China. ${ }^{4}$ Guangxi Colleges and Universities Key Laboratory of Prevention and Control of Highly Prevalent Diseases, Guangxi Medical University, Nanning 530021, China.
Received: 21 January 2017 Accepted: 29 January 2018

Published online: 12 February 2018

\section{References}

1. Ferlay J, Bray F, Pisani P, Parkin DM. Globocan 2000: cancer incidence, mortality and prevalence worldwide. Lyon: International Agency for Research on Cancer Press; 2001.

2. Siegel RL, Miller KD, Jemal A. Cancer statistics, 2016. CA Cancer J Clin. 2016; 66:7-30.

3. van Dijk BA, Karim-Kos HE, Coebergh JW, Marres HA, de Vries E. Progress against laryngeal cancer in The Netherlands between 1989 and 2010. Int Cancer. 2014;134(3):674-81.

4. Yang L, Parkin DM, Ferlay J, Li L, Chen Y. Estimates of cancer incidence in China for 2000 and projections for 2005. Cancer Epidemiol Biomark Prev. 2005:14(1):243-50.

5. Hashibe M, Brennan P, Chuang SC, Boccia S, Castellsague X, Chen C, Curado MP, Dal Maso L, Daudt AW, Fabianova E, et al. Interaction between tobacco and alcohol use and the risk of head and neck cancer: pooled analysis in the international head and neck cancer epidemiology consortium. Cancer Epidemiol Biomark Prev. 2009;18(2):541-50.

6. Khanna KK, Jackson SP. DNA double-strand breaks: signaling, repair and the cancer connection. Nat Genet. 2001;27(3):247-54.

7. Lins S, Kim R, Kruger L, Chrzanowska KH, Seemanova E, Digweed M. Clinical variability and expression of the NBN c.657del5 allele in Nijmegen breakage syndrome. Gene. 2009;447(1):12-7.

8. Hu Y, Scully R, Sobhian B, Xie A, Shestakova E, Livingston DM. RAP80directed tuning of BRCA1 homologous recombination function at ionizing radiation-induced nuclear foci. Genes Dev. 2011;25(7):685-700.

9. Bergs JW, Krawczyk PM, Borovski T, ten Cate R, Rodermond HM, Stap J, Medema JP, Haveman J,Essers J, van Bree C, et al. Inhibition of homologous recombination by hyperthermia shunts early double strand break repair to non-homologous end-joining. DNA repair(Amst). 2013;12(1):38-45.

10. Takeda S, Hoa NN, Sasanuma H. The role of the Mre11-Rad50-Nbs1 complex in double-strand break repair-facts and myths. J Radiat Res. 2016;57(Suppl):i25-32.

11. Zhang G, Zeng Y, Liu Z, Wei W. Significant association between Nijmegen breakage syndrome 1657 del5 polymorphism and breast cancer risk. Tumour Biol. 2013;34(5):2753-7.

12. Silva J, Teixeira AL, Lobo F, Mauricio J, Medeiros R. DNA repair system and prostate cancer progression: the role of NBS1 polymorphism (rs1805794). DNA Cell Biol. 2012;31(7):1182-6.

13. Gao P, Ma N, Li M, Tian QB, Liu DW. Functional variants in NBS1 and cancer risk: evidence from a meta-analysis of 60 publications with 111 individual studies. Mutagenesis. 2013;28(6):683-97.

14. Desjardins S, Beauparlant JC, Labrie Y, Ouellette G, Durocher F. Variations in the NBN/NBS1 gene and the risk of breast cancer in non-BRCA1/2 French Canadian families with high risk of breast cancer. BMC Cancer. 2009;9:181.

15. Ziólkowska I, Mosor M, Wierzbicka M, Rydzanicz M, Pernak-Schwarz M, Nowak J. Increased risk of larynx cancer in heterozygous carriers of the I171V mutation of the NBS1 gene. Cancer Sci. 2007:98(11):1701-5.

16. Nowak J, Mosor M, Ziółkowska I, Wierzbicka M, Permak-Schwarz M, Przyborska M, Roznowski K, Plawski A, Slomski R, Januszkiewicz D. Heterozygous carriers of the I171V mutation of the NBS1 gene have a significantly increased risk of solid malignant tumours. Eur J Cancer. 2008:44(4):627-30.

17. Li N, Xu Y, Zheng J, Jiang L, You Y, Wu H, Li W, Wu D, Zhou Y. NBS1 rs 1805794G $>$ C polymorphism is associated with decreased risk of acute myeloid leukemia in a Chinese population. Mol Biol Rep. 2013;40(5): $3749-56$.

18. Huang MD, Chen XF, Xu G, Wu QQ, Zhang JH, Chen GF, Cai Y, Qi FZ. Genetic variation in the NBS1 gene is associated with hepatic cancer risk in a Chinese population. DNA Cell Biol. 2012;31(5):678-82.

19. Fang W, Qiu F, Zhang L, Deng J, Zhang H, Yang L, Zhou Y, Lu J. The functional polymorphism of NBS1 p.Glu185GIn is associated with an increased risk of lung cancer in Chinese populations: case-control and a meta-analysis. Mutat Res. 2014;770:61-8.

20. Zheng J, Zhang C, Jiang L, You Y, Liu Y, Lu J, Zhou Y. Functional NBS1 polymorphism is associated with occurrence and advanced disease status of nasopharyngeal carcinoma. Mol Carcinog. 2011;50(9):689-96.

21. Li JT, Zhong BY, Xu HH, Qiao SY, Wang G, Huang J, Fan HZ, Zhao HC. Associations between NBS1 polymorphisms and colorectal cancer in Chinese population. PLoS One. 2015;10(7):e0132332. 
22. Yang L, Li Y, Cheng M, Huang D, Zheng J, Liu B, Ling X, Li Q, Zhang X, Ji W, et al. A functional polymorphism at microRNA-629-binding site in the $3^{\prime}$-untranslated region of NBS1 gene confers an increased risk of lung cancer in southern and eastern Chinese population. Carcinogenesis. 2012;33(2):338-47.

23. Stockwell HG, Goldman AL, Lyman GH, Noss Cl, Armstrong AW, Pinkham PA, Candelora EC, Brusa MR. Environmental tobacco smoke and lung cancer risk in nonsmoking women. J Natl Cancer Inst. 1992;84(18):1417-22.

24. Ruidavets JB, Ducimetière $P$, Evans $A$, Montaye $M$, Haas B, Bingham A, Yarnell J, Amouyel P, Arveiler D, Kee F, et al. Patterns of alcohol consumption and ischaemic heart disease in culturally divergent countries: the prospective epidemiological study of myocardial infarction(PRIME). BMJ. 2010;341:c6077.

25. Plisiecka-Halasa J, Dansonka-Mieszkowska A, Rembiszewska A, Bidzinski M, Steffen J, Kupryjanczyk J. Nijmegen breakage syndrome gene (NBS1) alterations and its protein (nibrin) expression in human ovarian tumours. Ann Hum Genet. 2002;66(Pt5-6):353-9.

26. Xu JL, Hu LM, Huang MD, Zhao W, Yin YM, Hu ZB, Ma HX, Shen HB. ShuYQ. Genetic variants of NBS1 predict clinical outcome of platinum-based chemotherapy in advanced non-small cell lung cancer in Chinese. Asian Pac J Cancer Prev. 2012;13(3):851-6.

27. Smith TR, Levine EA, Freimanis Rl, Akman SA, Allen GO, Hoang KN, Liu-Mares W, Hu JJ. Polygenic model of DNA repair genetic polymorphisms in human breast cancer risk. Carcinogenesis. 2008;29(11):2132-8.

28. Dumon-Jones V, Frappart PO, Tong WM, Sajithlal G, Hulla W, Schmid G, Herceg Z, Digweed M, Wang ZQ. Nbn heterozygosity renders mice susceptible to tumor formation and ionizing radiation-induced tumorigenesis. Cancer Res. 2003;63(21):7263-9.

29. Cerosaletti KM, Morrison VA, Sabath DE, Willerford DM, Concannon P. Mutations and molecular variants of the NBS1 gene in non-Hodgkin lymphoma. Genes Chromosomes Cancer. 2002;35(3):282-6.

30. Lu J, Wei Q, Bondy ML, Li D, Brewster A, Shete S, Yu TK, Sahin A, Meric-Bernstam F, Hunt KK, et al. Polymorphisms and haplotypes of the NBS1 gene are associated with risk of sporadic breast cancer in non-Hispanic white women $<\mathrm{or}=55$ years. Carcinogenesis. 2006;27(11):2209-16.

31. Sobti RC, Shekari M, Kordi Tamandani DM, Kaur P, Suri V, Huria A. Effect of NBS1 gene polymorphism on the risk of cervix carcinoma in a northern Indian population. Int Biol Marker. 2008;23(3):133-9.

32. Zhang Y, Huang YS, Lin WQ, Zhang SD, Li QW, Hu YZ, Zheng RL, Tang T, Li XZ, Zheng XH. NBS1 Glu185GIn polymorphism and susceptibility to urinaryn system cancer: a meta-analysis. Tumor Biol. 2014;35:10723-9.

33. Jelonek K, Gdowicz-Klosok A, Pietrowska M, Borkowska M, Korfanty J, Rzeszowska-Wolny J, Widlak P. Association between single-nucleotide polymorphisms of selected genes involved in the response to DNA damage and risk of colon, head and neck, and breast cancers in a polish population. J Appl Genet. 2010;51(3):343-52.

34. Liu J, Lončar I, Collée JM, Bolla MK, Dennis J, Michailidou K, Wang Q, Andrulis IL, Barile M, Beckmann MW, Behrens S, et al. rs2735383, located at a microRNA binding site in the $3^{\prime} U T R$ of NBS1, is not associated with breast cancer risk. Sci Rep. 2016:6:36874.

35. Han J, Haiman C, Niu T, Guo Q, Cox DG, Willett WC, Hankinson SE, Hunter DJ. Genetic variation in DNA repair pathway genes and premenopausal breast cancer risk. Breast Cancer Res Treat. 2009;115(3):613-22.

36. Wu Z, Wang P, Song C, Wang K, Yan R, Li J, Dai L. Evaluation of miRNA-binding-site SNPs of MRE11A, NBS1, RAD51 and RAD52 involved in HRR pathway genes and risk of breast cancer in China. Mol Gen Genomics. 2015;290(3):1141-53.

\section{Submit your next manuscript to BioMed Central and we will help you at every step:}

- We accept pre-submission inquiries

- Our selector tool helps you to find the most relevant journal

- We provide round the clock customer support

- Convenient online submission

- Thorough peer review

- Inclusion in PubMed and all major indexing services

- Maximum visibility for your research

Submit your manuscript at www.biomedcentral.com/submit
Biomed Central 